\title{
Correction: usage of documented pre-hospital observations in secondary care: a questionnaire study and retrospective comparison of records
}

\author{
Geir $\mathrm{O}$ Knutsen ${ }^{1}$ and Knut Fredriksen ${ }^{2^{*}}$
}

\section{Correction}

After the publication of our research article [1], we noticed that incorrect numbers were reported for the five lower parameters in the published Table three (Table 1 here). The published numbers derive from Table two in the article and were mistakenly copied into Table three (Table 1 here). This correction contains the corrected numbers for Table three (Table 1 here).

\section{Author details}

'Anaesthesia and Critical Care Research Group, Department of Clinical Medicine, Faculty of Health Sciences, University of Troms $\varnothing$, Tromsø N-9037, Norway. ${ }^{2}$ Division of Emergency Medical Services, University Hospital of North Norway, Tromsø N-9038, Norway.

Received: 8 January 2014 Accepted: 10 January 2014 Published: 22 January 2014

\section{References}

1. Knutsen GO, Fredriksen K: Usage of documented pre-hospital observations in secondary care: a questionnaire study and retrospective comparison of records. Scand I Trauma Resusc Emerg Med 2013, 21:13.

Table 1 Transfer of parameters to the hospital records: HEMS

\begin{tabular}{lccc}
\hline & PRF & EPR & \\
\hline Respiratory rate & 42 & 8 & $(19.0)$ \\
Oxygen saturation & 27 & 7 & $(25.9)$ \\
Mechanisms of injury & 26 & 26 & $(100.00)$ \\
GCS score & 45 & 24 & $(53.3)$ \\
Oxygen therapy & 117 & 36 & $(30.8)$ \\
Fluid therapy & 82 & 18 & $(22.0)$ \\
Medications provided & 91 & 66 & $(72.5)$ \\
Immobillization & 23 & 15 & $(65.2)$ \\
\hline
\end{tabular}

Parameters recorded in the pre-hospital report form (PRF) and in the ED clinician's admission note in the electronic patient record (EPR).

Patients admitted with helicopter emergency medical service (HEMS). N = 122.

* Correspondence: knut.fredriksen@unn.no

${ }^{2}$ Division of Emergency Medical Services, University Hospital of North Norway, Tromsø N-9038, Norway

Full list of author information is available at the end of the article doi:10.1186/1757-7241-22-3

Cite this article as: Knutsen and Fredriksen: Correction: usage of documented pre-hospital observations in secondary care: a questionnaire study and retrospective comparison of records. Scandinavian Journal of Trauma, Resuscitation and Emergency Medicine 2014 22:3.

\section{Submit your next manuscript to BioMed Central and take full advantage of:}

- Convenient online submission

- Thorough peer review

- No space constraints or color figure charges

- Immediate publication on acceptance

- Inclusion in PubMed, CAS, Scopus and Google Scholar

- Research which is freely available for redistribution

Submit your manuscript at

www.biomedcentral.com/submit

() Biomed Central
C Biomed Central

(C) 2014 Knutsen and Fredriksen; licensee BioMed Central Ltd. This is an Open Access article distributed under the terms of the Creative Commons Attribution License (http://creativecommons.org/licenses/by/2.0), which permits unrestricted use, distribution, and reproduction in any medium, provided the original work is properly cited. The Creative Commons Public Domain Dedication waiver (http://creativecommons.org/publicdomain/zero/1.0/) applies to the data made available in this article, unless otherwise stated. 